\title{
Land-Use Changes and Food Insecurity around Oil Palm Plantations: Evidence at the Village Level
}

\author{
Jajat Sudrajat ${ }^{1, *}$, Adi Suyatno ${ }^{2}$, Shenny Oktoriana ${ }^{3}$ \\ ${ }^{1}$ Department of Agricultural Socioeconomics, Faculty of Agriculture, Universitas Tanjungpura, Pontianak- \\ Indonesia; jajat.sudrajat@faperta.untan.ac.id \\ 2 Department of Agricultural Socioeconomics, Faculty of Agriculture, Universitas Tanjungpura, Pontianak- \\ Indonesia; adi.suyatno@faperta.untan.ac.id \\ 3 Department of Agricultural Socioeconomics, Faculty of Agriculture, Universitas Tanjungpura, Pontianak- \\ Indonesia; shenny.oktoriana@faperta.untan.ac.id \\ * Correspondence author: jajat.sudrajat@faperta.untan.ac.id; Tel.: 081256045003
}

\begin{abstract}
Land conversion of oil palm plantations in the villages of West Kalimantan has caused drastic changes in how farmers fulfill their basic household needs. One such change affects farmers' food security. This study aimed to explain the deterioration of food self-sufficiency at the village level due to the pressure to use residual pockets of land for oil palm cultivation. The collected evidence was analyzed through an assessment of their residual pockets of land in a single village. A case study survey collected data from July until September 2019 in the village of Batu Barat, district of Kayong Utara, West Kalimantan Province, Indonesia. The study utilized 70 family heads as samples for interviews. They were selected through a simple random sampling technique. We used descriptive quantitative and qualitative methods in our investigation. The results confirmed that the current utilization of the village's residual lands actually entails even greater food insecurity for farmers, as exemplified by a sizeable decrease in rice fields to merely an estimated 0.59 hectares per household. By contrast, the land utilized by independent smallholders of oil palm cultivation increased to an average of approximately 0.67 hectares per household. This land conversion not only exacerbated food-farmland availability but also deepened income dependency on a single commodity and the wage labor of the oil palm company.
\end{abstract}

Keywords: independent smallholders; land conversion; residual pockets of land; single commodity

\section{Introduction}

The massive expansion of the Indonesian oil palm industry has drastically altered many aspects of village life (McCarthy, 2010). Earlier studies on oil palm adoption in Indonesia highlight the contradiction between its positive and negative impacts on farmers' welfare. Some studies relate the impressive contribution of oil palm plantations to farmer income (Feintrenie et al., 2010; Budidarsono et al., 2012a; Budidarsono et al., 2012b). However, other research underscores its adverse effect on rural income inequality (Mukti et al., 2014; Euler et al., 2017; Bou Dib, et al., 2018). In addition, oil palm expands socioeconomic gaps (Semedi, 2014) and decreases the overall rate of improvement for social and environmental well-being (Santika et al., 2019a). Although it provides significant economic benefits to villagers, these are limited to villages that already had established plantation and market economies. Meanwhile, in villages that are based on traditional subsistence, oil palm tends to deteriorate socio-ecological welfare (Santika et al., 2019b).

There are two types of oil palm plantation management in Indonesia: company plantation, private or state-owned, and small-holders plantation (Fadjar, 2006; Obidzinski et al., 2012; Dharmawan et al., 2016). In the company type, both private or state-owned might adopt a nucleus estate smallholders (NES) scheme, depending on the social processes of the business permit when the oil palm company is established. The participating farmers, so-called plasma or dependent smallholders, obtain shares in the form of oil palm fields from the company of approximately 2 hectares in land size. On the other hand, the smallholders plantation is established by individual 
initiatives, generally as a response to livelihood changes occurring in a village (Belcher et al., 2004; Feintrenie et al., 2010).

The involvement of farmers in oil palm plantations raises a dilemma and creates more complex problems. The root of the problems could be identified in two forms. The first form is the complexity of the NES scheme. It is triggered by a fundamental weakness of the adopted paradigm, namely the economic relationships. Such a relationship is situated in an asymmetrical power context and tends to be exploitative. The company's dominance characterizes asymmetry in power to control the benefits generated in the business (Fadjar, 2006). This dominance has led the farmers to become powerless. For example, when sharing the plasma's land plots, the farmers often received plots in unfavorable areas (Dharmawan et al., 2016). Therefore, this practice often creates confusion among the farmers because their rights are unclear (Julia \& White, 2012). The second form is the complexity of problems due to the presence of independent smallholders. This problem is considered to encourage land scarcity for other commodities and environmental degradation because their location can be spatially scattered in rural areas, which are relatively difficult to control. Consequently, their expansion could also reach conservation areas (Diantoro, 2011; Euler et al., 2016; Hidayah et al., 2016; Dharmawan et al., 2020).

Oil palm expansion by large-scale companies is recognized as the leading cause of farmland scarcity in rural villages, although extensification of small-holders plantations also causes a similar problem, yet on a smaller scale (Obidzinski et al., 2012; Euler et al., 2016). The growing extent of oil palm plantation in both types of management should receive special attention since such expansions mostly take their residual pocket of land. Eventually, the continuing land conversion into oil palm plantations will affect land availability to grow other agricultural commodities, especially crops for daily food and subsistence needs. This land loss puts pressure on crop diversification opportunities and alternative income sources to lead to food insecurity in the context of the village level (Koczberski et al., 2012; Sinaga, 2013). Other studies in Sumatra show that the oil palm expansion has replaced the existing crops. The plantation has become an important competitor for rubber (Schwarze et al., 2015) and rice (Susanti \& Burgers, 2013; Zahri et al., 2019). A similar phenomenon also occurs in the present research. The intensity of land-use pressure is critical to study to obtain empirical evidence in the context of rural areas of West Kalimantan.

Several facts above give indications that the benefits of oil palm adoption for development strategy in rural areas still raise questions, especially regarding their model that must be guarantee food security to be self-sustained at a village level. As such, there is a need to assess the benefit of oil palm adoption. The assessment must be associated with the sustainable livelihood perspective because we believe that the latter is critical for development (Scoones, 2009). We argue that the optimal utilization of the residual pockets of land within a village for food diversification is the final means to prevent greater risk. This entails that food crop diversification should be a priority for farmer communities around oil palm plantations.

In this case, it is interesting to understand the land-use changes in the context of subsistencebased villages that occur around large-scale oil palm plantations. While there is a study that investigated such changes in the regional context of Kalimantan (Santika et al., 2019b), we argue that a site scale analysis is needed to check the phenomena on the ground. We hypothesize that the conversion of residual pockets of land, especially from the farmland of rubber and rice, will continue. Thus, it could be the most severe threat to food self-sufficiency and the environment and farming culture in the villages. This study aimed to explain the deterioration of food self-sufficiency at the village level due to the pressure to use residual pockets of land for oil palm cultivation.

\section{Methods}

This study took place in the village of Batu Barat within the subdistrict of Simpang Hilir, district of Kayong Utara, West Kalimantan Province, Indonesia (see Figure 1). Food farmland scarcity was a principal reason for our selection of this village. The difficulty villagers experienced in accessing food farmlands increased once an oil palm plantation was established in the village. The company has a nucleus estate of approximately 11,580 hectares and a smallholder estate of around 1,048 hectares. Batu Barat is also hemmed in by the Gunung Palung National Park (GPNP) on its south edge, which 
contains roughly $108,043.90$ hectares. The presence of a conservation area bordering the study location added a unique context to this study.

A case study survey was performed from July until September 2019. To collect primary data, the study used three methods: interviews, observation, and focus group discussion (FGD). The interview sessions were administered via structured and unstructured interviews. Meanwhile, direct observation was conducted to better understand the farmers' daily activities in the village. Finally, the FGD collected data from key informants, including selected respondents, village officers, and community leaders. FGD is a useful method for cross-checking and deepening findings or information collected through interviews and observation. The number of samples for structured interviews was approximately $15 \%$ of the 454 households in Batu Barat. Thus, we interviewed 70 family heads. The participants were selected via a simple random sampling technique involving the household list of each sub-village.

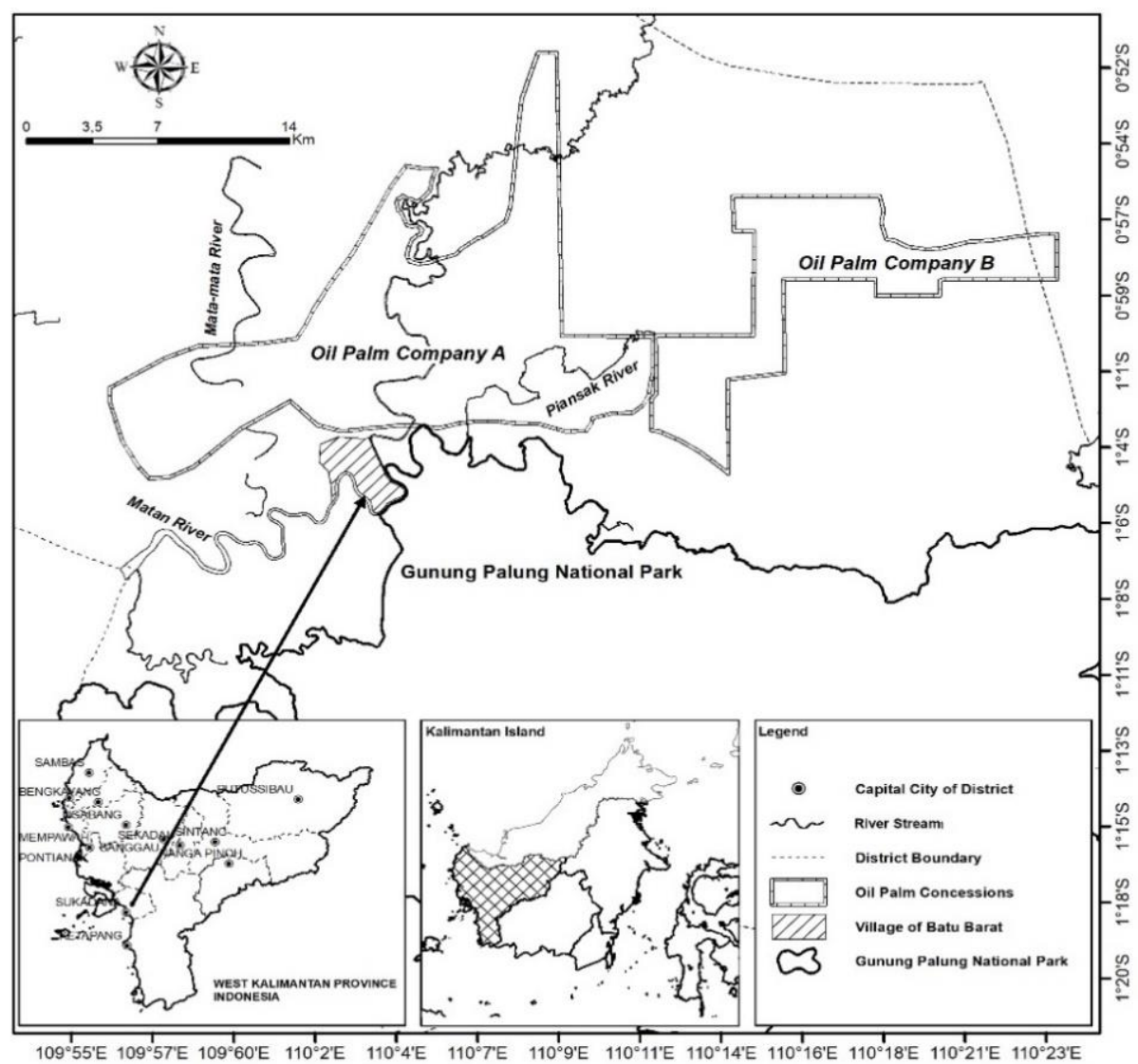

Figure 1. The site for the study in the village of Batu Barat, the district of Kayong Utara

Data from this study were analyzed through quantitative and qualitative descriptive methods. The quantitative method analyzed residual farmland utilization for each type of crop and social class of the farmers in the village. It was also used to identify the job types available to rural households. In the next stage, the data were verified, analyzed, and presented in table form. Meanwhile, the qualitative analysis shed light on Batu Barat's existing social institutions. Qualitative data were presented in a narrative style to elaborate upon the facts and phenomena.

\section{Results and Discussion}

We developed the results of this study focusing on four main issues involving food insecurity due to the presence of oil palm plantations. The first part explains the utilization of residual pockets of land within the village and describes the phenomenon of land access limitation based on social classes. The second part elucidates certain ongoing problems with rice farming that constitute a formidable challenge. Next, the discussion shifts to villagers' access to nonagricultural employment 
and the problems generated by dependence on the single commodity of oil palm. Finally, the section explains the general effect of oil palm adoption on migration, followed by some conclusions.

\subsection{The Utilization of Residual Pockets of Land}

Batu Barat lies on the side of the Matan River, which flows on its south and west edges. The Matan River must also be crossed to reach Gunung Palung National Park. The plantation area of the company borders the north and east sides of the village (see Figure 1). Batu Barat has an area of roughly 18,320 hectares with a population of approximately 2,104 people. Traditionally, this village is inhabited by the Kayong-Malay (Melayu) tribe, which mostly lives in four hamlets: Matan Raya, Sepakat, Rembayan, and Teluk Aur.

The study's results revealed that the demographic conditions of this village remain unsatisfactory because the educational background is still relatively low. More than half of the population (56\%) was illiterate, and approximately $34 \%$ graduated from elementary school. The farmers' ages ranged between 22 and 81 years, and the average family consisted of 4 people (Table 1).

Table 1. Rural household characteristics

\begin{tabular}{llc}
\hline \multicolumn{1}{c}{ Variables } & \multicolumn{1}{c}{$\begin{array}{c}\text { Category/ } \\
\text { descriptive results }\end{array}$} & $\begin{array}{c}\text { Proportion } \\
\text { (\%) }\end{array}$ \\
\hline Sample size $(\mathrm{n})$ & 70 respondents & \\
Farmers' age & $22-81$ years & \\
Family size & Average $=4$ people & \\
Educational level & Illiterate & 55.71 \\
& Elementary school & 34.29 \\
& Junior high school & 1.43 \\
& Senior high school & 5.71 \\
& University & 1.43 \\
\hline
\end{tabular}

In the past, the majority of villagers depended on traditional subsistence-based livelihoods, including traditional rice farming, rubber agroforestry, foraging, and fishing. However, their livelihoods have changed since oil palm plantations arrived in 2007, entailing a decrease in traditional livelihood systems. Currently, with respect to certain circumstances in the village, Batu Barat farmers are entering into new livelihood contexts. The most prominent is the increase in farmland scarcities, particularly for food crops.

At present, rice production is barely sufficient. Farmers only produce rice for six months of subsistent needs. Over the following months, farmers depend largely on the rice supply from outside of Batu Barat. This rice farming activity was only completed within the village, where farmland has decreased drastically. This study shows that the average rice field size was approximately 0.59 hectares per household. Approximately $33 \%$ of households held rice fields of less than 0.5 hectares. Roughly $30 \%$ of households had between 0.5 and 1 hectare, while only around $4 \%$ had more than 1 hectare (Table 2). Unexpectedly, approximately $33 \%$ of households did not hold any rice fields. This evidence might indicate that the control of Batu Barat farmers over their staple food has decreased dramatically.

Table 2. Number of rural households among each type of farming and farmland size

\begin{tabular}{cccc}
$\begin{array}{c}\text { Types of farming and farmland } \\
\text { size (hectares) }\end{array}$ & $\begin{array}{c}\text { Average } \\
\text { farmland size } \\
\text { (hectares) }\end{array}$ & $\begin{array}{c}\text { Respondents } \\
\text { (n) }\end{array}$ & $\begin{array}{c}\text { Proportion } \\
(\%)\end{array}$ \\
\hline
\end{tabular}

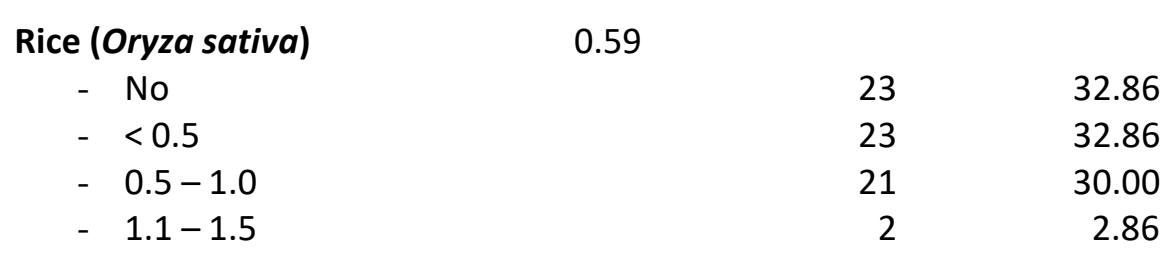




\begin{tabular}{|c|c|c|c|}
\hline $\begin{array}{c}\text { Types of farming and farmland } \\
\text { size (hectares) }\end{array}$ & $\begin{array}{c}\text { Average } \\
\text { farmland size } \\
\text { (hectares) }\end{array}$ & $\begin{array}{l}\text { Respondents } \\
\text { (n) }\end{array}$ & $\begin{array}{l}\text { Proportion } \\
\text { (\%) }\end{array}$ \\
\hline$-1.6-2.0$ & & 1 & 1.43 \\
\hline Rubber (Hevea brasiliensis) & 0.61 & & \\
\hline- No & & 26 & 37.14 \\
\hline$-<0.5$ & & 21 & 30.00 \\
\hline$-0.5-1.0$ & & 16 & 22.86 \\
\hline$-1.1-1.5$ & & 5 & 7.14 \\
\hline$-1.6-2.0$ & & 1 & 1.43 \\
\hline$->2$ & & 1 & 1.43 \\
\hline Oil Palm (Elaeis guineensis) & 0.67 & & \\
\hline$-\mathrm{No}$ & & 42 & 60.00 \\
\hline$-<0.5$ & & 8 & 11.43 \\
\hline$-0.5-1.0$ & & 17 & 24.29 \\
\hline$-\quad 1.1-1.5$ & & 1 & 1.43 \\
\hline$-1.6-2.0$ & & 2 & 2.86 \\
\hline
\end{tabular}

Keys: * Independent smallholders of oil palm

Both the rice fields and the rubber (Hevea brasiliensis) field size per household significantly decreased following the advent of oil palm cultivation. On average, the rubber fields were left at 0.61 hectares. Strikingly, the rural households lacking rubber crops were also quite high, at approximately $37 \%$. Meanwhile, about $53 \%$ had less than 1 hectare, with only around $10 \%$ having more than 1 hectare. By contrast, the number of households with independent oil palm fields continued to increase, comprising roughly $40 \%$ of the total rural households. Their land size averaged 0.67 hectares (Table 2 ).

Collectively, these facts demonstrate how the utilization of residual land inside the village for oil palm tended to expand. Given their previous experience, it is natural for farmers who live near large-scale plantations to grow a large amount of the same crop-this also occurred when the rubber crop was introduced during the Dutch era.

Economically, the increase in oil palm expansion in the residual land is reasonable: oil palm cultivation requires less labor than rubber as an alternative crop. Unfortunately, farmers were often more eager to expand cultivation rather than increase their yields per hectare (Euler et al., 2017). In the present study, this issue was exacerbated by the low price of latex, which has lasted for a long period. Hence, it was common for farmers to convert a part of or an entire rubber field into oil palm.

As to environmental degradation, independent smallholder expansion is more harmful than its industrial counterpart because it is not under government control. Smallholder expansion can also damage various types of landscape ecologies. For instance, they might use communal lands or even protected forest areas (Euler et al., 2016). Accordingly, the smallholder expansion of oil palm cultivation potentially threatens some protected plant and wild animal species, such as orangutans in Kalimantan (Meijaard et al., 2018).

\subsection{Land-Use Based on Social Classes}

Fulfilling household consumption needs usually requires a villager to employ their own assets or access other livelihood assets through social institutions. The access to and ownership of livelihood assets is determined by social classes in the community, demonstrating whether someone is in a village's upper, middle, or lower social class. In Batu Barat, the social classes were determined by farmland ownership. In the farmer community, those with more farmland were part of the upper social class. Concerning Batu Barat's social structure of farmland ownership, the classes included three categories: (i) the lower class, if farmland ownership was $\leq 0.75$ hectares; (ii) the middle class, if farmland ownership ranged from 0.751 to 1.5 hectares; and (iii) the upper class, if farmland ownership was more than 1.5 hectares. This social stratification is illustrated in Table 3. 
Table 3. Number of rural households for each type of farming and social class

\begin{tabular}{|c|c|c|c|c|c|c|}
\hline \multirow{2}{*}{ Types of farming } & \multicolumn{2}{|c|}{$\begin{array}{c}\text { Upper class } \\
(n=18)\end{array}$} & \multicolumn{2}{|c|}{$\begin{array}{c}\text { Middle class } \\
(n=23)\end{array}$} & \multicolumn{2}{|c|}{$\begin{array}{l}\text { Lower class } \\
(\mathrm{n}=29)^{*}\end{array}$} \\
\hline & $n$ & $\begin{array}{c}\text { Proportion } \\
(\%)^{* *}\end{array}$ & $n$ & $\begin{array}{l}\text { Proportion } \\
(\%)^{* *}\end{array}$ & $\mathrm{n}$ & $\begin{array}{c}\text { Proportion } \\
(\%)^{* *}\end{array}$ \\
\hline Rice (Oryza sativa) & 17 & 94.4 & 17 & 73.9 & 13 & 44.8 \\
\hline Rubber (Hevea brasiliensis) & 16 & 88.9 & 16 & 69.6 & 13 & 44.8 \\
\hline Oil Palm (Elaeis guineensis)*** & 12 & 66.7 & 11 & 47.8 & 5 & 17.2 \\
\hline
\end{tabular}

Keys: *Six households (21\%) of the lower class lack rice fields; ${ }^{* *}$ The total proportion of farmland ownership for each social class is over $100 \%$ because each household could practice more than one type of farming; ${ }^{* * *}$ Independent smallholders of oil palm

Table 3 shows that farmland access vulnerability was prominent among lower-class farmers, who comprised $41 \%$ of the total number of rural households. In this social class, approximately $21 \%$ of farmers lacked farmland. Land loss had forced them to work as farm laborers in the village or as wage laborers for the oil palm company. Indeed, only about $17 \%$ of lower-class households held independent oil palm fields. Meanwhile, in the middle and upper social classes, these numbers were approximately $48 \%$ and $67 \%$, respectively (Table 3 ). These facts demonstrate that all social classes in the village look forward to expanding their oil palm fields. On average, the oil palm field sizes of the upper and lower social classes exceeded their rice and rubber field sizes (Table 4).

Table 4. Average farmland size per household for each type of farming and social class

\begin{tabular}{lccc}
\hline \multirow{2}{*}{ Types of farming } & \multicolumn{3}{c}{ Average farmland size per household (hectares) } \\
\cline { 2 - 4 } & Upper class & Middle class & Lower class \\
\hline Rice (Oryza sativa) & 0.78 & 0.60 & 0.34 \\
Rubber (Hevea brasiliensis) & 0.92 & 0.56 & 0.29 \\
Oil Palm (Elaeis guineensis) & 0.94 & 0.51 & 0.37 \\
\hline
\end{tabular}

Keys: *Independent smallholders of oil palm

The expansion of independent oil palm fields could also be studied through the increasing fresh fruit bunch (FFB) trade, which involves middlemen. In this study, 3 middlemen originated from the Batu Barat, and several came from other villages. The farmers sold their products to these middlemen because the company's oil mill did not want to buy FFBs from the farmers near the company; this policy represented an effort to prevent FFB theft from the company's farm. This contrasts with other villages, where the FFBs were often sold to the nearest mills owned by largescale companies (Euler et al., 2016).

Furthermore, Table 4 confirms that Batu Barat's social classes primarily determined the individual scale of oil palm adoption. It follows that oil palm substantially widened the income gaps between social classes. The income disparity stemmed from the reduced labor required by oil palm farming, which affected the fate of socioeconomic relations between social classes. For instance, the labor relationships on farms are restricted to owners and daily casual laborers. Certainly, this phenomenon is much different from rubber farming, where labor absorption is higher, particularly in tapping. Rubber tapping is often achieved through profit-sharing patterns between owners and rubber tappers, entailing greater income distribution among social classes in the village.

In Batu Barat, therefore, the presence of oil palm plantations only benefited a few groups of people and undermined traditional livelihood systems. For farmers able to trade and accumulate many plots of oil palm fields, these circumstances may be rather favorable. By contrast, those who are in the lower social class are only able to work as low-wage laborers. Furthermore, the work cannot be easily performed by all villagers given that working on oil palm plantations is very strenuous. Thus most types of plantation work are not suitable for women, elderly people, or people with a physical disability (de Vos, 2016). 


\subsection{The Problem of Rice Farming}

Land conversion for oil palm monoculture imperils food security (Nesadurai, 2013), particularly for subsistence-based farmers (Santika et al., 2019a). This phenomenon could develop into a food crisis at the micro level (Sinaga, 2013), especially if the FFBs experience long-term price pressure akin to that currently experienced by rubber products. Food sovereignty also becomes an essential issue in the context of the global market and climate uncertainty. Therefore, the potential loss of the ability to produce food constitutes a vulnerability phenomenon.

In this study, farmers in Batu Barat planted rice once a year, and their cultivation method was sedentary. However, their cultivation technique did not significantly change compared to the previous period, when the land areas around the village were still abundant. Currently, the farming practice is characterized by a lack of tillage, fertilization, or added organic material, such as livestock manure or compost. The addition of nutrients stemmed only from burning bushes to prepare farmland. Yet this method is unsustainable due to the imbalance between the flow of nutrients into the soil and plant absorption. As mentioned above, Batu Barat's farmers also typically maintain a subsistence-based orientation.

To facilitate rice cultivation, the traditional social institution used was "berandep", involving an exchange of household workers who alternately help each other (reciprocity) to accomplish several stages of work that could not be handled by individual households. This institution was suited to provide sufficient labor when the stages in rice farming were labor-intensive, such as during the planting or harvesting stage. However, it was rarely implemented during the land clearing stage because the cutting of bushes was commonly followed by land burning.

Land scarcity was not the only cause of farmers' vulnerability. Increasing pest attacks also reduced the enthusiasm of farmers to pursue rice farming. Interestingly, the increase in rice pests might be associated with the presence of oil palm plantations-a complaint some farmers expressed.

Although symptoms of vulnerability have emerged, they have yet to cause social upheavals because the community in this rural area has a high tolerance and solid kinship culture as a foundation for creating harmonious social relations. The social classes discussed above were not exclusive. The present study discovered that they were simply used to divide the farmers' roles more clearly within the community. For instance, those who were in the upper class would be able to help others in the lower class amid economic hardships. The reciprocal norms were preserved, reflecting how Batu Barat's community was both original and unpretentious. For instance, it had not yet developed a land-rent institution, while the norms for land rent through a lease were somewhat lax. Leasing land for rice farming only cost a few sacks of rice, and when the harvest was unsuccessful, the rental rules could be even more lenient.

\subsection{Livelihood and the Dependency on Wage Labor of Oil Palm Companies}

Nonfarm employment diversification plays a critical role when the income from farming is inadequate. Generally, a household can more easily diversify its income if it already has substantial assets (Gebru et al., 2018). It is normal across all social classes: for instance, when a farmer opens a small shop or business that sells daily necessities. For Batu Barat's farmers, members of the lower class performed the most diversification within off-farm and nonfarm employment in the village, including farm laborers, wood craftsman, roof crafts, and other daily works. The lower and middle classes also responded to an inadequate income by utilizing family labor to access job opportunities within the oil palm companies, where their proportions were estimated at $55 \%$ and $48 \%$, respectively (Table 5). This number indicates a high dependency on the wage labor of the oil palm industry.

Positions in the oil palm industry that were easier to access included a casual labor role called "BHL" (Buruh Harian Lepas). Adult men mostly worked as harvesters, security personnel, and drivers, while women had lighter types of work such as fertilizing, applying herbicides, and collecting individual fruits called "brondolan" that fell around trees or in other places. The most difficult position to obtain was any type of permanent employment. This depended on the worker's time with the company, expertise, loyalty, and other aspects of its management's considerations. 
Table 5. Off-farm and nonfarm jobs for each social class

\begin{tabular}{|c|c|c|c|c|c|c|}
\hline \multirow{2}{*}{$\begin{array}{l}\text { Off-farm and } \\
\text { nonfarm jobs }\end{array}$} & \multicolumn{2}{|c|}{ Upper class ( $n=18)$} & \multicolumn{2}{|c|}{ Middle class $(n=23)$} & \multicolumn{2}{|c|}{ Lower class ( $n=29)$} \\
\hline & $\mathrm{n}$ & $\begin{array}{c}\text { Proportion } \\
\text { (\%) }\end{array}$ & $\mathrm{n}$ & $\begin{array}{l}\text { Proportion } \\
\text { (\%) }\end{array}$ & $\mathrm{n}$ & $\begin{array}{l}\text { Proportion } \\
\text { (\%) }\end{array}$ \\
\hline Small shop & 2 & 11.11 & 0 & 0 & 2 & 6.90 \\
\hline $\begin{array}{l}\text { Swallows' nest } \\
\text { business }\end{array}$ & 0 & 0 & 1 & 4.35 & 1 & 3.45 \\
\hline $\begin{array}{l}\text { Laborers of oil palm } \\
\text { companies }\end{array}$ & 6 & 33.33 & 11 & 47.83 & 16 & 55.17 \\
\hline $\begin{array}{l}\text { Laborers of mining } \\
\text { companies }\end{array}$ & 2 & 11.11 & 2 & 8.70 & 2 & 6.90 \\
\hline $\begin{array}{l}\text { Laborers of others } \\
\text { company }\end{array}$ & 0 & 0 & 0 & 0 & 1 & 3.45 \\
\hline $\begin{array}{l}\text { Farm laborers inside } \\
\text { the village }\end{array}$ & 0 & 0 & 2 & 8.70 & 2 & 6.90 \\
\hline Wood craftsman & 0 & 0 & 0 & 0 & 1 & 3.45 \\
\hline Roof crafts & 0 & 0 & 1 & 4.43 & 1 & 3.45 \\
\hline Teacher & 1 & 5.56 & 0 & 0 & 0 & 0 \\
\hline
\end{tabular}

Based on the number of jobs that could be accessed in the on-farm, off-farm, or nonfarm sectors, the farmer income in Batu Barat typically comprised these six major sources:

1. Income as a casual laborer (BHL). Their wage was approximately 100,000 IDR (=7.05 USD) per day. Permanent employees received approximately 2-3 million IDR per month (depending on the length of employment as a worker), including enough rice for two children.

2. Income from plasma fields. This income fluctuated with the price of international crude palm oil (CPO), the cost of fertilizer and maintenance, and FFB production. It was frequently less than 500,000 IDR per month, although sometimes it reached nearly 1.5 million IDR per month.

3. Income from independent oil palm fields. This income was determined by farmland size, crop age, FFB production, and local FFB prices. The farmer's FFB price tended to be lower than the company's for quality reasons. Today, this income is typically less than 1 million IDR per month.

4. Income from rubber fields. This income fluctuated with crop age, farmland size, and local latex prices. Recently, the latex price has often been suppressed to between 4000 and 5000 IDR per kilogram. Hence, on average, a farmer's income was less than 500,000 IDR per month.

5. Income from rice fields. This was determined by farmland size, production, and local prices. However, no farmers in Batu Barat sold their rice during the study because their personal needs for the year had not yet been met.

6. Nonfarm income. This was still too small to estimate because the job opportunities were not yet fully developed.

These income sources illustrate how oil palm adoption has impressively contributed to farmers' income, though blemished by environmental degradation and certain social problems, such as conflicts over land ownership and unevenly distributed economic benefits (Obidzinski et al., 2012). In Batu Barat, farmers from all social classes shared mostly positive perceptions regarding their current income (Table 6). 
Table 6. Farmers' perceptions of income, food sufficiency, and rice production after the establishment of the oil palm plantation

\begin{tabular}{|c|c|c|c|c|}
\hline \multirow[b]{2}{*}{ Questions and aspects } & \multicolumn{3}{|c|}{ Proportion on each social class (\%) } & \multirow{2}{*}{$\begin{array}{l}\text { Total }(\%) \\
(\mathrm{n}=70)\end{array}$} \\
\hline & $\begin{array}{l}\text { Upper } \\
(n=18)\end{array}$ & $\begin{array}{l}\text { Middle } \\
(\mathrm{n}=23)\end{array}$ & $\begin{array}{l}\text { Lower } \\
(n=29)\end{array}$ & \\
\hline \multicolumn{5}{|c|}{$\begin{array}{l}\text { Do you think your household income is } \\
\text { better? }\end{array}$} \\
\hline Agree & 77.8 & 52.2 & 69 & 65.7 \\
\hline Disagree & 22.2 & 47.8 & 31 & 34.3 \\
\hline \multicolumn{5}{|c|}{$\begin{array}{l}\text { Do you think your food sufficiency is } \\
\text { better? }\end{array}$} \\
\hline Agree & 77.8 & 43.5 & 65.5 & 61.4 \\
\hline Disagree & 22.2 & 56.5 & 34.5 & 38.6 \\
\hline \multicolumn{5}{|c|}{ Do you think rice production is better? } \\
\hline Agree & 11.1 & 8.7 & 6.9 & 8.6 \\
\hline Disagree & 88.9 & 91.3 & 93.1 & 91.4 \\
\hline
\end{tabular}

Regarding income perceptions, approximately $66 \%$ of farmers noticed an increase in their income (Table 6). This result was indicated by their general satisfaction with an increase in disposable income. Likewise, food sufficiency was perceived to be better due to an increase in farmers' purchasing ability. This reinforces a previous study in which oil palm adoption demonstrated a positive impact on food and non-food expenditures, calorie consumption, and dietary quality (Euler et al., 2017). By contrast, the negative perception of rice production aligns with the average size of rice farmland, which decreased significantly.

The issue of oil palm adoption at the industrial scale has simulated academic debate. For example, the holistic perspective holds that an increase in income for the current generation does not guarantee farmers' welfare for future generations. This interpretation stems from other facts, particularly those concerning future farmland availability. There are also certain problems related to the NES scheme regarding participant-farmer income. Although the plasma fields provide regular income every month, this income is usually insufficient. Hence, this income source is only capable of fulfilling food consumption; it is not enough to push farmers' households above the poverty line.

This limited income encouraged some individual farmers to sell their plasma plots through an informal sale. However, according to government regulations, these land plots could not legally be sold. Moreover, this decision to sell will only worsen farmers' current situation and complicate future economic problems. The loss of land plots entails economic hardships for the younger generation and will trigger more conflicts between farmers and the company. Today, the conflict comprises several recurring land claims because farmers do not think the company fulfills its promises or claims about plasma plots. This situation mirrors a previous study detailing how conflicts are often caused by companies' attitudes and failures to keep their promises (Abram et al., 2017). Such conflicts were further aggravated by indistinct land ownership rights (Rist et al., 2010).

The conversion of residual land into oil palm agriculture was also closely related to the limited income from plasma fields. This might indicate the ineffectiveness of plantation developments that adopted the NES scheme. Research demonstrated how the NES scheme did not significantly reduce the vulnerability of participant-farmers to poverty (Cahyadi \& Waibel, 2016). Moreover, this pattern contributed to the farmers' dependence on the oil palm company and put them in a disadvantaged position (Semedi \& Bakker, 2014). Therefore, in practice, plasma fields were not capable of equitably distributing benefits to farmers. One of the problems was a time lag; too much time elapsed between a farmer's access to the natural resources around the village decreasing and generating sufficient income from plasma fields.

Furthermore, oil palm adoption was and is incapable of guaranteeing decent intergenerational livelihoods. Although it appeared as if it would reduce poverty for current farmers, it impoverished millions of people during the next generation. Thus, it would only deepen and strengthen the 
poverty, despair, and social devastation of the villagers around plantations (Li, 2017). In addition, it was also found that oil palm intervention on an industrial scale weakened women's livelihood positions, which were heavily involved in traditional mixed farming, increasing social problems including prostitution and gender violence (Julia \& White, 2012).

Other scholars calculated that the income from plasma fields is unlikely to guarantee future prosperity for younger generations (Elmhirst et al., 2017) because land loss will limit their access. Land access is essential for food security, income stability, and flexibility when encountering crises and market opportunities (de Vos, 2016). Furthermore, it is truly worrisome that the fates of future generations will likely be disconnected from subsistence agriculture, whether they continue as laborers paid by plantations or spend their lives as contract farmers. This issue has the potential to destroy or preserve agricultural futures (White, 2012). We believe that crop monoculture at the industrial scale will not answer this challenge.

\subsection{Effect on Migration}

The migration strategy is a natural phenomenon among all social classes of communities. In Batu Barat, the middle and lower social classes had the most migration (Table 7). In general, the drive for migration was to seek jobs in the urban sector. Land loss could be a determinant of this migration event, which aimed to increase household income (Vanwey, 2003). Here, all of the migrating workers were young people. There was also a tendency to use unmarried children as laborers to help the household during economic hardship.

Table 7. Migration-out of the villagers among each social class in Batu Barat

\begin{tabular}{lcccccc}
\hline Migration types & $\mathrm{n}$ & $\begin{array}{c}\text { Proportion } \\
(\%)\end{array}$ & $\mathrm{n}$ & $\begin{array}{c}\text { Proportion } \\
(\%)\end{array}$ & $\mathrm{n}$ & $\begin{array}{c}\text { Proportion } \\
(\%)\end{array}$ \\
\cline { 2 - 7 } & 0 & 0 & 0 & 0 & 2 & 6.90 \\
\hline $\begin{array}{l}\text { Migration-out to the } \\
\text { district city center }\end{array}$ & 0 & 11.11 & 4 & 17.39 & 3 & 10.34 \\
$\begin{array}{l}\text { Migration-out to the } \\
\text { province city center }\end{array}$ & 2 & & & & & \\
\hline
\end{tabular}

In this study, the principal factor triggering young people in Batu Barat to migrate was low income. Meanwhile, the pull factor was the number of job opportunities within urban areas. This result confirmed earlier findings, in which one of the migration decisions was determined by household income (Chakraborty \& Kuri, 2017). However, the migration rate from this village was minimal, whereby the excess labor due to land loss could still be accommodated through existing opportunities in the village, such as jobs in the off-farm and nonfarm sectors.

\section{Conclusions}

Oil palm adoption produced livelihood changes in the village of Batu Barat. Rice fields significantly decrease and become around 0.59 hectares per household. As the rice yield is small, farmers usually buy more rice to suffice their household needs. Likewise, the ownership of rubber fields decreased to an average of approximately 0.61 hectares. By contrast, the ownership of independent oil palm fields increased to roughly 0.67 hectares per household. This transformation of residual lands into independently cultivated oil palm will likely continue, although, as participant farmers, Batu Barat's villagers received oil palm fields from the company of approximately 2 hectares.

The utilization of the residual pockets of land for independent oil palm (Elaeis guineensis) production was unexpected because it entrenches farmers' dependence on a single commodity and harms the environment. Therefore, this condition creates a context for vulnerability; it undermines farmers' food security. Subsequently, it will restrict the access of the younger generation to subsistence farmland. Accordingly, what farmers should be concerned about is whether fresh fruit bunches of oil palm will be subject to long-term price pressures similar to the rubber commodity 
today. In other words, this scheme entails great risk and uncertainty in the context of the global market and international political economy.

This result confirms the need for policy-making that directs oil palm production toward lower risks and more equitable income distribution, ensuring land access for the future of rural youth. Moreover, specific efforts from the government and companies are urgently needed to empower farmers residing around oil palm plantations, particularly in how they utilize their residual pockets of land for cultivating food crops.

Conflicts of Interest: The authors declare no conflict of interest.

Acknowledgments: We would like to thank Universitas Tanjungpura for making this research possible by providing financial assistance. Additionally, we greatly appreciate the dean and staff of the agricultural faculty who facilitated this research.

\section{References}

Abram, N.K., Meijaard, E., Wilson, K.A., Davis, J.T., Wells, J.A., Ancrenaz, M., Budiharta, S., Durrant, A., Fakhruzzi, A., Runting, R.K., Gaveau, D., \& Mengersen, K. (2017). Oil palm-community conflict mapping in Indonesia: A case for better community liaison in planning for development initiatives. Applied Geography, 78, 33-44. https://doi.org/10.1016/j.apgeog.2016.10.005

Belcher, B., Rujehan, Imang, N., \& Achdiawan, R. (2004). Rattan, Rubber, or Oil Palm: Cultural and Financial Considerations for Farmers in Kalimantan. Economic Botany, 58, 77- 87.

Bou Dib, J., Alamsyah, Z., \& Qaim, M. (2018). Land-use change and income inequality in rural Indonesia. Forest Policy and Economics, 94, 55-66. https://doi.org/10.1016/j.forpol.2018.06.010

Budidarsono, S., Dewi, S., Sofiyuddin, M., \& Rahmanulloh, A. (2012a). Socioeconomic Impact Assessment of Palm Oil Production. Technical Brief No. 27: Palm Oil Series. Bogor, Indonesia: World Agroforestry Centre-(ICRAF), SEA Regional Office. $4 \mathrm{p}$

Budidarsono, S., Rahmanulloh, A., \& Sofiyuddin, M. (2012b). Economic Assessment of Palm Oil Production. Technical Brief No. 26: Palm Oil Series. Bogor, Indonesia: World Agroforestry Centre-(ICRAF), SEA Regional Office. 6p.

Cahyadi, E.R. \& Waibel, H. (2015). Contract Farming and Vulnerability to Poverty among Oil Palm Smallholders in Indonesia. The Journal of Development Studies, 52(5), 681-695. https://doi.org/10.1080/00220388.2015.1098627

Chakraborty, D. \& Kuri, P.K. (2017). The Household Level Determinants in the Choice and Level of Migration: A Micro Study in West Bengal. Environment and Urbanization ASIA, 8(1), 94-104. https://doi.org/10.1177/0975425316683864

de Vos, R.E. (2016). Multi-Functional Lands Facing Oil Palm Monocultures: A Case Study of a Land Conflict in West Kalimantan, Indonesia. Austrian Journal of South-East Asian Studies, 9(1), 11 32.

Dharmawan, A.H., Mardiyaningsih, D.I., Komarudin, H., Ghazoul, J., Pacheco, P., \& Rahmadian, F. (2020). Dynamics of Rural Economy: A Socio-Economic Understanding of Oil Palm Expansion and Landscape Changes in East Kalimantan, Indonesia. Land, 9, 213. https://doi.org/10.3390/land9070213

Dharmawan, A.H., Mardiyaningsih, D.I., \& Yulian, B.E. (2016). Ekspansi Perkebunan Kelapa Sawit dan Perubahan Sosial, Ekonomi dan Ekologi Pedesaan: Studi Kasus di Kutai Kartanegara. Project Working Paper Series OPAL (Oil Palm Adaptive Landscapes) No. 1. Pusat Studi Pembangunan Pertanian dan Pedesaan-Institut Pertanian Bogor.

Diantoro, T.D. (2011). Perambahan Kawasan Hutan pada Konservasi Taman Nasional (Studi Kasus Taman Nasional Tesso Nilo, Riau). Mimbar Hukum, 23(3), 546-565. https://doi.org/10.22146/jmh.16176

Elmhirst, R., Siscawati, M., Basnett, B.S., \& Ekowati, D. (2017). Gender and generation in engagements with oil palm in East Kalimantan, Indonesia: Insights from feminist political ecology. The Journal of Peasant Studies, 44(6), 1135-1157. 
https://doi.org/10.1080/03066150.2017.1337002

Euler, M., Krishna, V., Schwarze, S., Siregar, H., \& Qaim, M. (2017). Oil Palm Adoption, Household Welfare, and Nutrition Among Smallholder Farmers in Indonesia. World Development, 93, 219-235. https://doi.org/10.1016/j.worlddev.2016.12.019

Euler, M., Schwarze, S., Siregar, H., \& Qaim, M. (2016). Oil Palm Expansion among Smallholder Farmers in Sumatra, Indonesia. Journal of Agricultural Economics, 67(3), 658-676. https://doi.org/10.1111/1477-9552.12163

Fadjar, U. (2006). Kemitraan Usaha Perkebunan: Perubahan Struktur yang Belum Lengkap. Forum Penelitian Agro Ekonomi, 24(1), 46-60. http://dx.doi.org/10.21082/fae.v24n1.2006.46-60

Feintrenie, L., Chong, W. K., \& Levang, P. (2010). Why do Farmers Prefer Oil Palm? Lessons Learnt from Bungo District, Indonesia. Small-Scale Forestry, 9(3), 379-396. https://doi.org/10.1007/s11842-010-9122-2

Gebru, G.W., Ichoku, H.E., \& Phil-Eze, P.O. (2018). Determinants of livelihood diversification strategies in Eastern Tigray Region of Ethiopia. Agriculture \& Food Security, 7(1), 62. https://doi.org/10.1186/s40066-018-0214-0

Hidayah, N., Dharmawan, A.H., \& Barus, B. (2016). Ekspansi Perkebunan Kelapa Sawit dan Perubahan Sosial Ekologi Pedesaan. Sodality: Jurnal Sosiologi Pedesaan, 4(3), 249256. https://doi.org/10.22500/sodality.v4i3.14434

Julia \& White, B. (2012). Gendered experiences of dispossession: Oil palm expansion in a Dayak Hibun community in West Kalimantan. The Journal of Peasant Studies, 39(3-4), 995-1016. https://doi.org/10.1080/03066150.2012.676544

Koczberski, G., Curry, G.N., \& Bue, V. (2012). Oil palm, food security and adaptation among smallholder households in Papua New Guinea. Asia Pacific Viewpoint, 53(3), 288299. https://doi.org/10.1111/j.1467-8373.2012.01491.x

Li, T.M. (2017). Intergenerational displacement in Indonesia's oil palm plantation zone. The Journal of Peasant Studies, 44(6), 1158-1176. https://doi.org/10.1080/03066150.2017.1308353

McCarthy, J.F. (2010). Processes of inclusion and adverse incorporation: Oil palm and agrarian change in Sumatra, Indonesia. The Journal of Peasant Studies, 37(4), 821-850. https://doi.org/10.1080/03066150.2010.512460

Meijaard, E., Garcia-Ulloa, J., Sheil, D., Wich, S.A., Carlson, K.M., Juffe-Bignoli, D., \& Brooks, T.M. (eds.) (2018). Oil palm and biodiversity. A situation analysis by the IUCN Oil Palm Task Force. IUCN Oil Palm Task Force Gland, Switzerland: IUCN. Xiii + 116pp. https://doi.org/10.2305/IUCN.CH.2018.11.en

Mukti, A., Setiawan. B., Pramoedyo, H., \& Fatah, L. (2014). The Impact of Palm Oil Plantation Development towards Income Disparity. Academic Research International, 5(2), 96-106.

Nesadurai, H.E.S. (2013). Food security, the palm oil-land conflict nexus, and sustainability: a governance role for a private multi-stakeholder regime like RSPO?. The Pacific Review, 26(5), 505-529. http://dx.doi.org/10.1080/09512748.2013.842311

Obidzinski, K., Andriani, R., Komarudin, H., \& Andrianto, A. (2012). Environmental and Social Impacts of Oil Palm Plantations and their Implications for Biofuel Production in Indonesia. Ecology and Society, 17(1), art25. https://doi.org/10.5751/ES-04775-170125

Rist, L., Feintrenie, L., \& Levang, P. (2010). The livelihood impacts of oil palm: Smallholders in Indonesia. Biodiversity and Conservation, 19(4), 1009-1024. https://doi.org/10.1007/s10531010-9815-z

Santika, T., Wilson, K.A., Budiharta, S., Law, E.A., Poh, T.M., Ancrenaz, M., Struebig, M.J., \& Meijaard, E. (2019a). Does oil palm agriculture help alleviate poverty? A multidimensional counterfactual assessment of oil palm development in Indonesia. World Development, 120, 105-117. https://doi.org/10.1016/j.worlddev.2019.04.012

Santika, T., Wilson, K.A., Meijaard, E., Budiharta, S., Law, E.E., Sabri, M., Struebig, M., Ancrenaz, M., \& Poh, T.-M. (2019b). Changing landscapes, livelihoods and village welfare in the context of oil palm development. Land Use Policy, 87, 104073. https://doi.org/10.1016/j.landusepol.2019.104073 
Schwarze, S., Euler, M., Gatto, M., Hein, J., Hettig, E., Holtkamp, A. M., Izhar, L., Kunz, Y., Lay, J., Merten, J., Moser, S., Mußhoff, O., Otten, F., Qaim, M., Soetarto, E., Steinebach, S., Trapp, K., Vorlaufer, M., \& Faust, H. (2015). Rubber vs. oil palm: an analysis of factors influencing smallholders' crop choice in Jambi, Indonesia. EFForTS, Ecological and Socioeconomic Functions of Tropical Lowland Rainforest Transformation Systems (Sumatra, Indonesia), Discussion Paper Series No. 11. Georg-August-Universität Göttingen.

Scoones, I. (2009). Livelihoods perspectives and rural development. The Journal of Peasant Studies, 36(1), 171-196. https://doi.org/10.1080/03066150902820503

Semedi, P. (2014). Palm Oil Wealth and Rumour Panics in West Kalimantan. Forum for Development Studies, 41(2), 233-252. https://doi.org/10.1080/08039410.2014.901240

Semedi, P. \& Bakker, L. (2014). Between Land Grabbing and Farmers' Benefits: Land Transfers in West Kalimantan, Indonesia. The Asia Pacific Journal of Anthropology, 15(4), 376-390. https://doi.org/10.1080/14442213.2014.928741

Sinaga, H. (2013). Employment and income of workers on Indonesian oil palm plantations: food crisis at the micro-level. Future of Food: Journal on Food, Agriculture and Society, 1(2), 64-78.

Susanti, A. \& Burgers, P. (2013). Oil Palm Expansion: Competing Claim of Lands for Food, Biofuels, and Conservation. In Behnassi et al. (Eds.), Sustainable Food Security in the Era of Local and Global Environmental Change (301-320). Dordrecht, Netherland: Springer. https://doi.org/10.1007/978-94-007-6719-5_19

Vanwey, L.K. (2003). Land Ownership as a Determinant of Temporary Migration in Nang Rong, Thailand. Europen Journal of Population, 19(2), 121-145.

White, B. (2012). Agriculture and the Generation Problem: Rural Youth, Employment and the Future of Farming. IDS Bulletin, 43(6), 9-19. https://doi.org/10.1111/j.1759-5436.2012.00375.x

Zahri, I., Wildayana, E., Ak, A.T., Adriani, D., \& Harun, M.U. (2019). Impact of conversion from rice farms to oil palm plantations on socio-economic aspects of ex-migrants in Indonesia. Agricultural Economics, 65(12), 579-586. https://doi.org/10.17221/349/2018-AGRICECON . 